\title{
Review Article \\ Climate Change and Sugarcane Production: Potential Impact and Mitigation Strategies
}

\author{
Duli Zhao ${ }^{1}$ and Yang-Rui $\mathrm{Li}^{2}$ \\ ${ }^{1}$ USDA-ARS, Sugarcane Field Station, Canal Point, FL 33438, USA \\ ${ }^{2}$ Sugarcane Research Center, Chinese Academy of Agricultural Science, Guangxi Academy of Agricultural Sciences, \\ Nanning 530007, China \\ Correspondence should be addressed to Duli Zhao; duli.zhao@ars.usda.gov
}

Received 21 May 2015; Revised 15 September 2015; Accepted 17 September 2015

Academic Editor: Glaciela Kaschuk

Copyright (C) 2015 D. Zhao and Y.-R. Li. This is an open access article distributed under the Creative Commons Attribution License, which permits unrestricted use, distribution, and reproduction in any medium, provided the original work is properly cited.

\begin{abstract}
Sugarcane (Saccharum officinarum L.) is an important crop for sugar and bioenergy worldwide. The increasing greenhouse gas emission and global warming during climate change result in the increased frequency and intensity of extreme weather events. Climate change is expected to have important consequences for sugarcane production in the world, especially in the developing countries because of relatively low adaptive capacity, high vulnerability to natural hazards, and poor forecasting systems and mitigating strategies. Sugarcane production may have been negatively affected and will continue to be considerably affected by increases in the frequency and intensity of extreme environmental conditions due to climate change. The degree of climate change impact on sugarcane is associated with geographic location and adaptive capacity. In this paper, we briefly reviewed sugarcane response to climate change events, sugarcane production in several different countries, and challenges for sugarcane production in climate change in order for us to better understand effects of climate change on sugarcane production and to propose strategies for mitigating the negative impacts of climate change and improving sugarcane production sustainability and profitability.
\end{abstract}

\section{Introduction}

A combination of long-term change in the weather patterns worldwide (i.e., global climate change), caused by natural processes and anthropogenic factors, may result in major environmental issues that have affected and will continuously affect agriculture. Atmospheric $\mathrm{CO}_{2}$ concentration $\left(\left[\mathrm{CO}_{2}\right]\right)$ has increased by about $30 \%$ since the mid-18th century due to increases in combustion of fossil fuels, industrial processes, and deforestation [1]. Projections indicate that atmospheric $\left[\mathrm{CO}_{2}\right]$ would increase to about $550 \mathrm{ppm}$ in a low emission scenario or could double $(800 \mathrm{ppm})$ from current levels in a high emission scenario by the end of the 21st century. Global warming is directly associated with increasing atmospheric $\left[\mathrm{CO}_{2}\right]$ and other greenhouse gases (GHG). Global surface mean temperatures had increased from 0.55 to $0.67^{\circ} \mathrm{C}$ in the last century and are project to rise from 1.1 to $2.9^{\circ} \mathrm{C}$ (low emission) or 2.0 to $5.4^{\circ} \mathrm{C}$ (high emission) by 2100 relative to 1980-1999, depending on GHG emission level, region, and geographic location [2].
Increases in atmospheric $\left[\mathrm{CO}_{2}\right]$ and air temperature can be beneficial for some crops (especially $\mathrm{C}_{3}$ plants) in some places $[3,4]$. Climate variability and climate change are projected to result in changes in sea levels, rainfall pattern, and the frequency of extreme high- and low-temperature events, floods, droughts, and other abiotic stresses $[5,6]$ as well as tornados and hurricanes [7]. High temperatures accompanied by drought stress have been two of the major issues influencing agricultural production and economic impacts in many regions of the world. The challenges, faced by the agricultural sector under the climate change scenarios, are to provide food security for an increasing world population while protecting the environment and the functioning of its ecosystems [8]. For most countries that are highly dependent on rainfall with limited or no proper irrigation conditions and/or that have poor mitigation systems, these challenges may be amplified [9].

Agriculture is vulnerable to climate change through the direct effects of changing climate conditions (e.g., changes in temperature and/or precipitation), as well as through 
the indirect effects arising from changes in the severity of pest pressures, availability of pollination services, and performance of other ecosystem services that affect agricultural productivity. Reduction of crop productivity is universally predicted in most status reports on effects of climate change [10]. Climate change poses unprecedented challenges to agriculture because of the sensitivity of agricultural productivity and costs of improving growth environmental conditions. Adaptive action offers the potential to manage the effects of climate change by altering patterns of agricultural activity to capitalize on emerging opportunities while minimizing the costs associated with negative effects.

\section{Sugarcane Response to Climate Change Events}

Sugarcane is an important industrial crop used for sugar and bioenergy. It is one of the world's major $\mathrm{C}_{4}$ crops that mainly grow in the tropic and subtropic regions. Weather and climate related events (i.e., growth environment of atmospheric $\left[\mathrm{CO}_{2}\right]$, temperature, precipitation, and other extreme weather) are the key factors for sugarcane production worldwide, especially in many developing countries. The potential negative impact of climate change, especially temperature and rainfall, on sugarcane production in Zimbabwe has been reviewed by Chandiposha [15]. The sugarcane and sugar yields have fluctuated with extreme climate events (drought and tropical cyclones) [7]. A record sugar production (516,529 tonnes) in Fiji in 1994 was recorded because of favorable weather, but sugar productions in 1997, 1998, and 2003 were 47,50 , and $43 \%$, respectively, lower than that in 1994 due to drought environment [7].

By using crop simulation models, Marin at al. [16] reported that climate change improved sugarcane water use efficiency and cane yield in some areas of Brazil. They predicted that cane yield in 2050 could be $15-59 \%$ higher than that at the current average level. Studies have also indicated that elevated $\left[\mathrm{CO}_{2}\right]$ under controlled environment increased sugarcane photosynthesis, water use efficiency, biomass, and productivity [17-19]. Improved water use efficiency of sugarcane under elevated $\left[\mathrm{CO}_{2}\right]$ is mainly associated with the reduced stomatal conductance $[17,18]$. Although these findings from the controlled environment are important for better understanding of physiological mechanisms of sugarcane plant response to elevated $\left[\mathrm{CO}_{2}\right]$, they may not completely reveal the interactions of $\left[\mathrm{CO}_{2}\right]$ and other climate factors under field conditions. The most significantly positive effect would be on reduced incidence of frost, which is a major limitation on production [20] in most regions, such as Louisiana of USA, where growing season is short. When realizing these benefits, however, we have to take serious consideration for long-term negative impact on nutrient levels, soil moisture, water availability, and other conditions. A negative effect of increased temperature may occur in the tropical regions where cool winters are required to slow plant growth and increase sucrose storage. Probably the most dramatic effect of climate change on sugarcane production in Australia would be from the increase in sea level [21]. A significant proportion of sugarcane is grown along coastal areas. Any increase in sea level would make these areas difficult to farm and a large increase in sea level would require large areas to be abandoned [20]. The same is true in South Florida, USA.

High temperature due to climate change in Northeastern Brazil will increase the evapotranspiration rates reducing the amount of water available in soils, making the planting of sugarcane increasingly difficult [22] and considerably increasing irrigation demand [23]. Knox et al. [24] assessed climate change impacts on sugarcane production in Swaziland using crop modeling and found a decreasing trend for future projections for cane yield unless irrigation was included in the model because of high demand of irrigation. In the South Caribbean, sugarcane yield may decrease by $20-$ $40 \%$ under a doubled $\left[\mathrm{CO}_{2}\right]$ climate change scenario based on outputs of a crop model [25]. The decreased yield was mainly attributed to increased water deficit stress caused by the warmer climate. Although increases in atmospheric $\left[\mathrm{CO}_{2}\right]$ and air temperature may benefit sugarcane growth and biomass accumulation in some regions of the world based on studies in pots $[17,18]$ and under controlled conditions [19] or based on crop modeling prediction [16, 26], sugarcane production is highly vulnerable to climate change due to increased frequency and intensity of the extreme weather events, such as drought, heat, flooding, typhoon, and frost $[7,15,24,27-29]$.

Effects of drought due to climate change on sugarcane growth and development depend on plant growth stage, the degree of water deficit stress, and duration of the stress. In general, drought in early and mid growth stages mainly reduces cane yield leading to low sucrose yield. Moderate drought in late growth stage can improve sucrose content in stalks. Drought is the most important stress factor for sugarcane production in China, a country ranked the top third in sugarcane production in the world, because more than $80 \%$ of sugarcane grows under rainfed conditions [30]. Drought in 2003/2004 in Guangxi, China, resulted in an $18 \%$ decrease in cane yield [27]. Sugarcane production was recorded high in 2007/08 in Guangxi because of the ideal distribution of rainfall and other favorable growth environment conditions. Cane yield, cane production, and sugar production were $83.8 \mathrm{tha}^{-1}, 77.1 \mathrm{Mt}$, and $9.41 \mathrm{Mt}$, respectively. However, a long duration of extremely low temperature and rainy weather in the region from January to February 2008 and the freeze temperatures caused severe damage of most sugarcane. In December 2009, the extreme freeze temperatures $\left(-4\right.$ to $\left.-6^{\circ} \mathrm{C}\right)$ occurred again and drought in the 2010 early growing season (January-June) accompanied with severe freeze temperature in December resulted in considerable reduction in sugarcane production. Cane yield, cane production, and sugar production in 2010/11 dropped to $56.3 \mathrm{tha}^{-1}, 55.7 \mathrm{Mt}$, and $6.75 \mathrm{Mt}$, respectively [30, 31]. Similarly, drought conditions in 1983, 1997, 1998, and 2003 and the 1997 tropic cyclones in Fuji led to big decline (16$46 \%$ ) in sugarcane production, compared to production in record years $[7,13,14]$. Water logging is also a widespread phenomenon that drastically reduces the growth and survival 
of sugarcane and the water logging stress led to $18-64 \%$ reduction in cane yield [32], depending on duration of water logging, plant growth stage, and cultivars [32, 33].

A shift in temperature due to climate change will have an effect on some of diseases, insects, and weeds in sugarcane production [15]. For example, Matthieson [34] reported that the incidence of smut disease [caused by Sporisorium scitamineum (Syd.)] is likely to increase due to high temperatures. The prolific dry weather exacerbates the symptoms of ratoon stunting disease. It is difficult to predict the effect of climate change on sugarcane rust diseases, but severe storms and hurricane can spread leaf scald, caused by Xanthomonas albilineans [35]. The more extreme weather events due to climate change have caused more overwintering pests (weeds and insects), more disease pathogens, and more input costs for reducing these risks to maintain a certain level of sugarcane production. For instance, sugarcane leaf brown rust (caused by Puccinia melanocephala Syd. \& P. Syd.) and orange rust [caused by $P$. kuehnii (W. Krüger) E. J. Butler] diseases, especially orange rust, are big challenges for sugarcane production in Florida, USA [36-38]. Severity of rusts is associated with winter temperature and relative humidity in the region. Sugarcane orange rust in 2012 and 2013 in South Florida was the most severe since it was first found in 2007 [39] due to favorable climate conditions of warmer winter and high humidity for the rust spores surviving and fast development [38]. Growers used fungicides to control the negative effects of rusts on yields, but the cost of three split applications of fungicides (at a hectarage level) during a growing season was equivalent to 3 tonnes $(\mathrm{Mg})$ of cane yield lost per hectare. The economic impact just for controlling orange rust in South Florida was approximately $\$ 63$ million in 2013 based on the estimate of the Florida sugarcane industry.

The adaptation of farming systems to climate change in sugarcane production requires taking advantage of the potential benefits and minimizing potential adverse impacts on crop production. Therefore, a better understanding of the functions of these climate/weather factors and their impacts on sugarcane production can help manipulate plants to meet human needs and formulate adaptation or mitigation strategies. In the following parts of this paper, we attempt to briefly review sugarcane production in several different countries, such as Brazil, India, China, Thailand, Pakistan, and USA (developing and developed countries), to better understand effects of climate change on sugarcane production and to propose strategies for mitigating the negative impacts of climate change and improving sugarcane production sustainability and profitability.

\section{Sugarcane Production in Top 10 Countries}

The top 10 sugarcane production countries in the world in 2013 were Brazil, India, China, Thailand, Pakistan, Mexico, Colombia, Indonesia, Philippines, and USA and their cane productions (million $\mathrm{Mg}$ of cane) accounted for 34.1, 15.8, $5.8,4.6,2.9,2.8,1.6,1.6,1.5$, and $1.3 \%$ (a total of $72 \%$ ) of the world total cane production, respectively (Table 1). Cane yields $\left(\mathrm{Mg} \mathrm{ha}^{-1}\right)$ in these countries ranked 29th, 40th, 39th,
TABLE 1: The world top 10 sugarcane production countries in 2013 for their cane production, hectarage, and cane yield as well as their ranks in 103 sugarcane production countries.

\begin{tabular}{|c|c|c|c|c|c|c|}
\hline \multirow{2}{*}{ Country } & \multicolumn{2}{|c|}{ Production } & \multicolumn{2}{|c|}{ Area } & \multicolumn{2}{|c|}{ Yield } \\
\hline & Million Mg & Rank & $\times 1000$ ha & Rank & $\mathrm{Mg} \mathrm{ha}^{-1}$ & Rank \\
\hline Brazil & 739.27 & 1 & 9835.2 & 1 & 75.17 & 29 \\
\hline India & 341.20 & 2 & 5060.0 & 2 & 67.43 & 40 \\
\hline China & 126.14 & 3 & 1827.3 & 3 & 69.03 & 39 \\
\hline Thailand & 100.10 & 4 & 1321.6 & 4 & 75.74 & 26 \\
\hline Pakistan & 63.75 & 5 & 1128.8 & 5 & 56.48 & 51 \\
\hline Mexico & 61.18 & 6 & 782.8 & 6 & 78.16 & 25 \\
\hline Colombia & 34.88 & 7 & 405.7 & 9 & 85.95 & 19 \\
\hline Indonesia & 33.70 & 8 & 450.0 & 7 & 74.89 & 31 \\
\hline Philippines & 32.00 & 9 & 435.4 & 8 & 73.49 & 37 \\
\hline USA & 27.91 & 10 & 368.6 & 11 & 75.71 & 27 \\
\hline World total & 2165.23 & & 26522.7 & & 81.64 & \\
\hline
\end{tabular}

Source: FAO of the United Nations, FAOSTAT, and Factfish [13, 14].

26th, 51st, 25th, 19th, 31st, 37th, and 27th, respectively, in the 103 sugarcane production countries [13, 14]. In last 41 years, sugarcane production was linearly increased with years from 1973 to 2013 in all the top seven sugarcane production countries. Both sugarcane area and cane yield contributed to the increases in cane production, but increased area was a dominant contributor compared with cane yield except for Pakistan where increases in sugarcane hectarage and cane yield had similar proportion. Hectarage in Brazil, India, China, Thailand, Pakistan, Mexico, and Colombia increased by $500,94,237,286,57,52$, and $61 \%$, respectively, and cane yields increased by $60,38,59,70,58,11$, and $24 \%$, respectively, in last 41 years (1973-2013) based on linear regression. In the same period of years, sugarcane hectarage in USA increased only $31 \%$ and yield had no big change or slightly decreased (7.0\%) (Table 2).

Additionally, cane yield was lower and the yield variation (CV) across years was much greater in most developing countries than that in USA. Averaged across 41 years from 1973 to 2013, mean cane yields in Brazil, India, China, Thailand, and Pakistan were 17.8, 21.0, 25.1, 31.7, and 44.1\% lower, respectively, than that in USA (Table 2). Coefficient of variation $(\mathrm{CV})$ values for cane yields across years in these five countries ranged from 11.5 to $20.4 \%$ compared to a CV value of $5.7 \%$ in USA (Table 2). When plotting sugarcane hectarage and yield against year, neither hectarage nor yield in the top five sugarcane production countries leveled off and the slope (indicating cane yield increasing rate) of the linear regression in Table 2 ranged from 0.49 (India) to 0.75 (Brazil) $\mathrm{Mgha}^{-1} \mathrm{yr}^{-1}$. Although impact of climate change on sugarcane production depends on geographic location and on degree of adaptation, cane yields in most developing countries still tend to increase by improved cultivars and management practices. Therefore, increases in both sugarcane area and cane yield are still feasible in these countries in current environment. To consider increasing population and land limitation, improving sugarcane yields in future is more 
TABLE 2: Maximum, minimum, and mean cane yields and coefficient of variation (CV) across last 41 years (1973-2013) for the world top 10 sugarcane production countries. The slope and $r^{2}$ values of linear regression cane yield and year for each country are listed in the table ${ }^{\dagger}$.

\begin{tabular}{|c|c|c|c|c|c|c|}
\hline Country & $\begin{array}{c}\text { Maximum } \\
\left(\mathrm{Mgha}^{-1}\right)\end{array}$ & $\begin{array}{l}\text { Minimum } \\
\left(\mathrm{Mg} \mathrm{ha}^{-1}\right)\end{array}$ & $\begin{array}{c}\text { Mean } \\
\left(\mathrm{Mg} \mathrm{ha}^{-1}\right)\end{array}$ & $\begin{array}{l}\mathrm{CV} \\
(\%) \\
\end{array}$ & $\begin{array}{c}\text { Slope } \\
\left(\mathrm{Mgha}^{-1} \mathrm{yr}^{-1}\right) \\
\end{array}$ & $r^{2}$ \\
\hline Brazil & 80.26 & 46.48 & 64.92 & 14.33 & 0.75 & 0.93 \\
\hline India & 76.53 & 49.11 & 62.41 & 11.48 & 0.49 & 0.68 \\
\hline China & 74.93 & 39.18 & 59.16 & 15.98 & 0.67 & 0.73 \\
\hline Thailand & 76.20 & 30.14 & 53.93 & 20.42 & 0.70 & 0.58 \\
\hline Pakistan & 57.23 & 31.57 & 44.19 & 15.48 & 0.50 & 0.76 \\
\hline Mexico & 78.16 & 62.68 & 71.11 & 6.00 & 0.22 & 0.40 \\
\hline Colombia & 101.81 & 57.23 & 84.87 & 10.68 & 0.45 & 0.36 \\
\hline Indonesia & 149.02 & 55.17 & 84.08 & 26.57 & -1.60 & 0.73 \\
\hline Philippines & 96.52 & 58.59 & 74.27 & 11.94 & 0.25 & 0.12 \\
\hline USA & 89.98 & 69.90 & 78.99 & 5.71 & -0.14 & 0.14 \\
\hline World total & 71.77 & 53.76 & 62.49 & 8.68 & 0.45 & 0.95 \\
\hline
\end{tabular}

${ }^{\dagger}$ Data source: FAO of the United Nations (FAOSTAT) and Factfish [13, 14].

important compared to hectarage for sugarcane production, especially in most developing countries.

\section{Challenges for Sugarcane Production}

In general, great variation in sugarcane yields exists in most developing countries across years (Table 2) and regions with varying rainfall and temperature due to low adaptive capacity, high vulnerability to natural hazards, and poor forecasting system and mitigating strategies [7]. High inputs and high costs of the production and low cane price are also very common in these developing countries, which results in low profits for sugarcane growers. For instance, sugarcane growers in major production areas (Guangxi, Yunnan, Guangdong, and Hainan) in China have planted some more profitable crops because of the financial considerations [11]. Sugarcane hectarage in Guangxi, the largest cane producing province, is expected to drop $6 \%$ in 2014/15 as farmers grow the lowlabor input and fast-growing tree species for industrial use according to the Provincial Sugar Industry Bureau. Cane hectarage in Hainan is estimated to decline $11 \%$ in 2014/15 due to low profits according to provincial statistics. In addition to low prices, high labor costs have also contributed to a major part of low profitability. More than half of sugarcane hectarage is located in hilly areas where mechanized operation is unavailable and the use of hand labor for planting, field management, and harvesting considerably increases the input of labors. As the cost of labor continues to rise (\$20/Mg cane), which accounts for approximately $27 \%$ of cane price $(\$ 71 / \mathrm{Mg})$ in 2013/14, grower's profit from sugarcane was impacted considerably (Figure 1). Therefore, low prices of cane and high labor costs caused a great drop in net income for growers in 2013/14 [11]. Reducing production costs by introduction and development of creative technologies and expanding use of sugarcane products not only for sugar but also for ethanol, cellulosic biofuel, and other coproducts will improve profits under the current and future climate conditions.

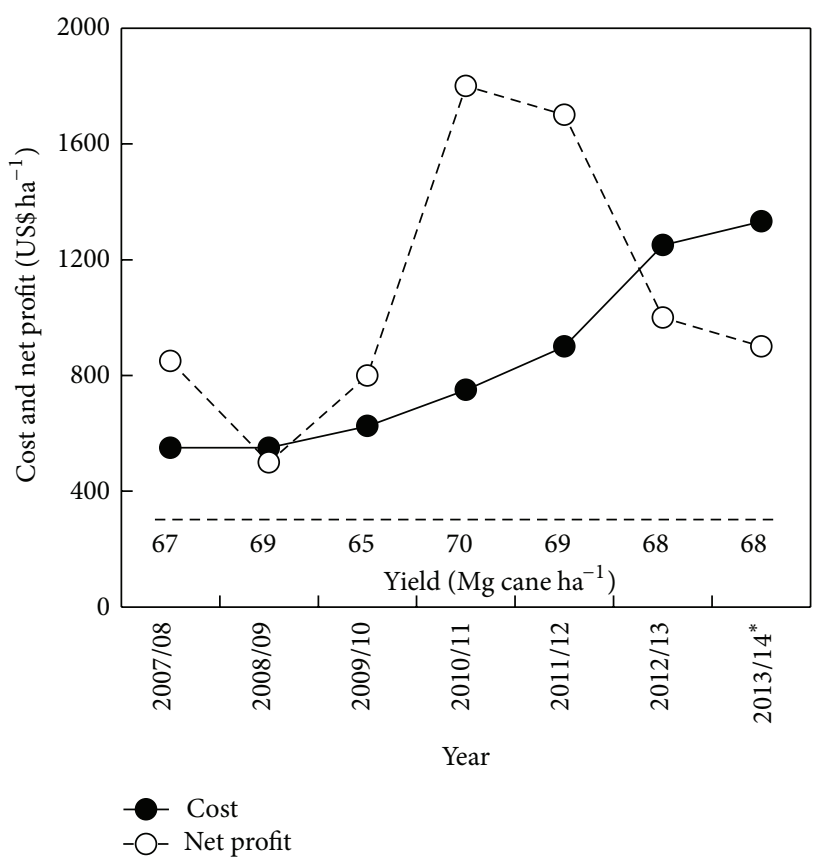

FIGURE 1: Average labor cost, net profit, and cane yield in major sugarcane production regions in China from 2007 to 2014. 2013/14* based on postestimate. Data are adopted from Anderson-Sprecher and Jiang [11].

When assessing agriculture and crop production systems as well as climate change and its negative impact on crop production, many economic, environmental, and social issues have to be thoroughly considered, such as how to (1) balance short-term and long-term goals; (2) increase productivity, profitability, and sustainability; (3) introduce new technologies and transfer them to growers; (4) meet environmental regulations; (5) deal with contradictions between climate change and crop production; and (6) balance competition of 


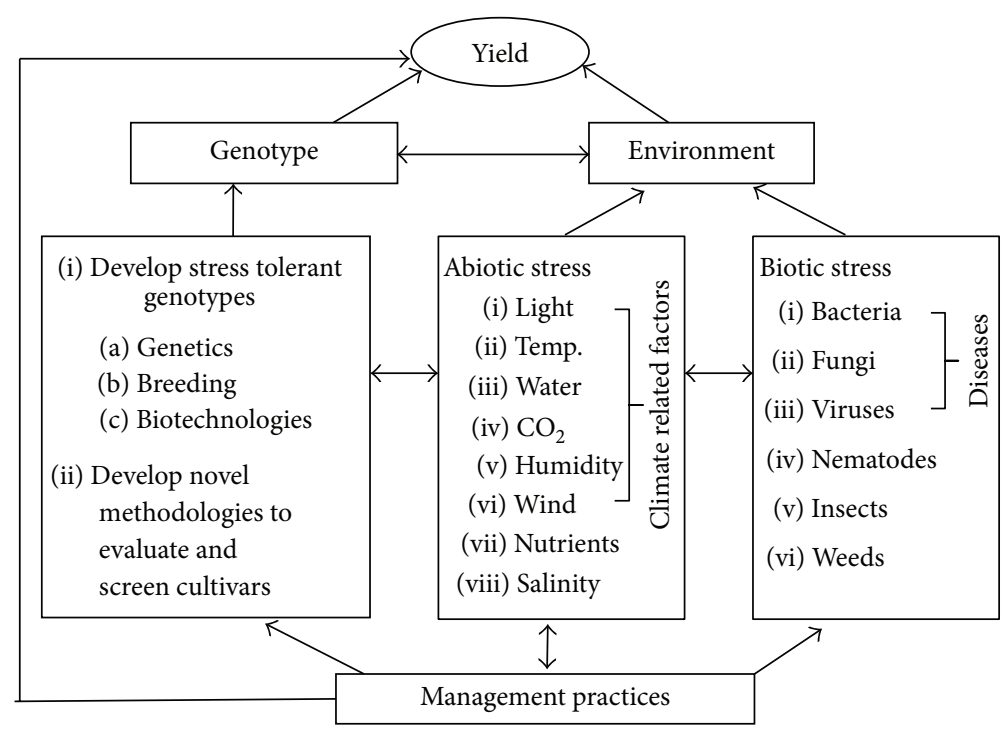

Figure 2: A flow chart to demonstrate major factors (genotype, environment, and management practices) influencing sugarcane yield as well as their interactions.

food and energy in resources. Certainly, sugarcane production systems are also challenged by these specific issues.

\section{Mitigating Impact of Stress Environment and Sustaining Sugarcane Production}

Although climate change increases the frequency and intensity of extreme weather events and uncertainty and vulnerability of adverse effects on agriculture [2, 6, 7, 9, 26, 29], the world sugarcane production was tripled in last 41 years $[13,14]$ because of increase in demand. The increased cane production was associated with increases in both hectarage and cane yield in most developing countries as described above. Much more efforts are needed to focus on increasing yield and improving profits under the current conditions and in the future climate change. Sugarcane yield relies on crop varieties (genotypes), biotic and abiotic growth environments (i.e., insects, diseases, weeds, and other climate related factors), and management practices (Figure 2).

Some mitigation and adaptation strategies for climate change in sugarcane production in Zimbabwe have recently been proposed [15] and these mitigation strategies included planting drought tolerant varieties, investing irrigation infrastructure, improving irrigation efficiency and drainage systems, and improving cultural and management practices. Based on long-term data collected in South Africa, Deressa et al. [40] suggested that adaptation strategies should focus special attention on technologies and management regimes that will enhance sugarcane tolerance to warmer temperatures during winter and especially the harvesting phases. Thus, development of the stress tolerant and high-yielding sugarcane cultivars is one of the important strategies in adaptation of climate change (Figure 2). Sugarcane breeders and other scientists can develop computer data base to design hybridization (within or between species) for special requirement in the breeding programs, use growth and physiological traits to screen elite clones for resistance/tolerance to biotic and abiotic stresses [41], and use tissue culture, molecular biology, and gene transformation technologies to improve breeding and selection efficiencies. Studies have shown that some genotypes/cultivars are better than others in tolerance to water deficit [41-43] and low temperature [13] stresses, in radiation use efficiency [44], and in nutrient use efficiency $[45,46]$.

Using 33-year data of sugarcane yields in Florida to estimate the contribution of a breeding program to sugarcane production, Edmé et al. [47] found that sucrose content, cane tonnage, and sugar yield of the Florida commercial sugarcane cultivars linearly increased by $26.0,15.5$, and $47.0 \%$, respectively, from 1968 to 2000 . They found that the increases in yield components mainly occurred on the Florida organic soils. Underscoring the critical need for cultivar development for the Florida sugarcane industry, about $69 \%$ of the sugar yield gain came from genetic improvement attributable to the Canal Point (CP) cultivar development program. Recently, we planted $12 \mathrm{CP}$-sugarcane cultivars/genotypes that have a wide range of released years (from 1980 to 2013) on sand soils at two locations in Florida in 2011. The 3-year results of this study indicated that sucrose yield linearly and positively related to the cultivar-released year $\left(r=0.77^{* *}\right)$. The increased sucrose yield on the Florida sand soils for the latest released cultivars was mainly associated with cane tonnage $\left(r=0.73^{* *}\right)$ rather than commercial recoverable sucrose $(r=0.17)$ (unpublished data, Figure 3). Based on pot and field studies with intensive measurements of physiological, growth, and yield traits, we also found that some sugarcane genotypes are more tolerant to stress environment than others [43, 46, 48]. Therefore, development of new sugarcane cultivars that can contribute to adaptation to climate change (especially for elevated $\mathrm{CO}_{2}$ and temperature) by discovering and introducing desirable genes for agronomic trait development [49] and using basic breeding [50], physiological screening [41, 43], and new 

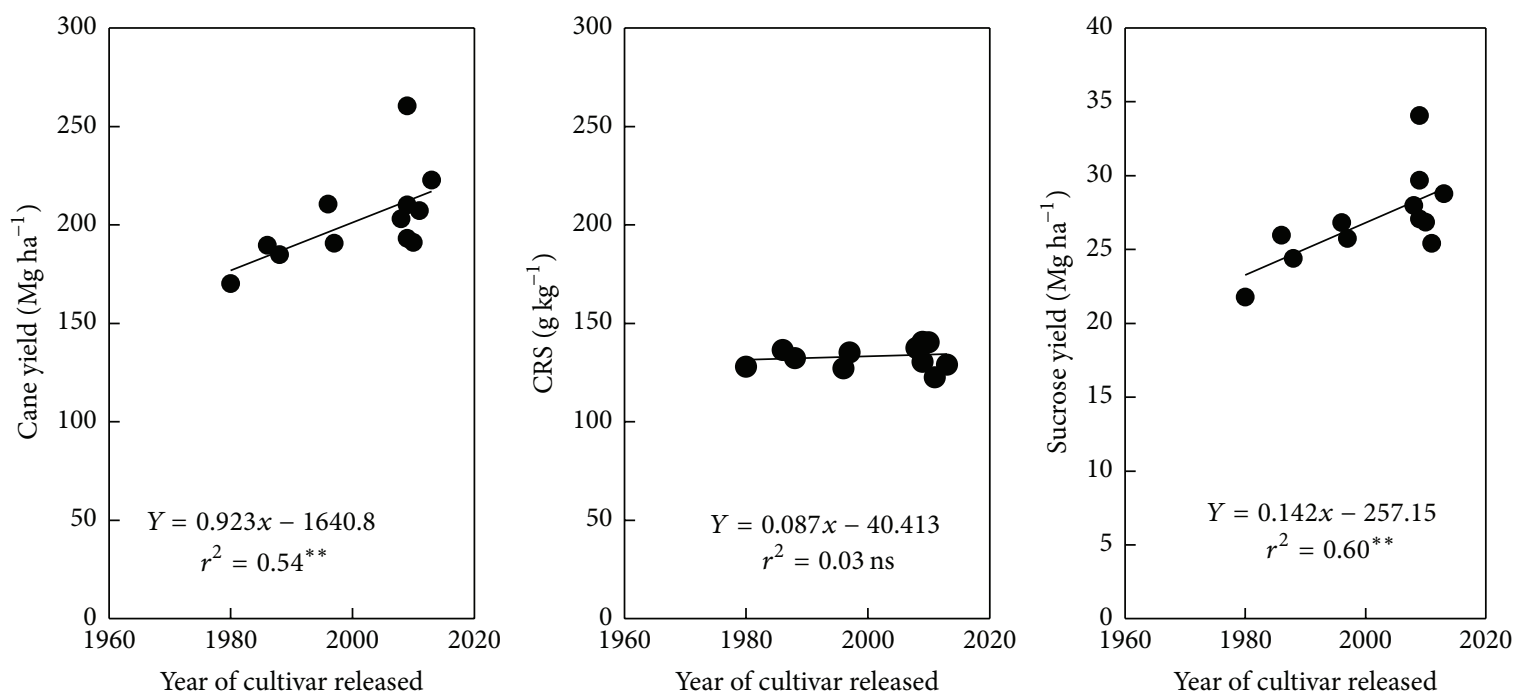

FIGURE 3: Trends of cane yield, commercial recoverable sucrose (CRS), and sucrose yield for 12 sugarcane cultivars or genotypes grown on sand soils at two locations in Florida. These cultivars had a wide range of released years from 1980 to 2013.

technologies of molecular biology [51] can mitigate the negative effect of climate change and improve sugarcane yields, productivity, and sustainability.

Using technologies of molecular biology and gene transformation to develop genetically modified (GM) sugarcane varieties [52-54], such as herbicide glyphosate resistance, drought tolerance, high sugar content, and disease resistance, may be one of the important ways to mitigate negative impacts of environmental stresses due to climate change. To address some of the potential concerns regarding safety of the GM sugarcane products, Joyce et al. [54] compared the GM sugarcane with non-GM control for product quality. They found that sugar crystallized from GM sugarcane plants did not contain residual DNA or proteins of introduced transgenes. The finding will improve the public perceptions surrounding GM sugar and its potential future incorporation within commercial sugarcane production.

Diversity of cropping systems, crops, and cultivars within a crop is also important for mitigating negative effect of climate change, biotic and abiotic stresses, or other uncertain extreme climate events because there are considerable differences among plant species, cultivars, and cropping systems in tolerance to stresses. Sugarcane cultivar Q124 in Queensland, Australia, in 2000 accounted for $45 \%$ of the crop, but a new race of orange rust pathogen devastated this high-performing cultivar and caused the industry Aus\$150-210 million in yield losses $[55,56]$. In a region, therefore, sugarcane variety diversity is also imperative for reducing risk of extreme climate factors, for mitigating negative effects of stress environment, and for improving sustainability of sugarcane production. Sugarcane cultivars with a wide range of maturity can buffer the harvest time and reduce the pressure of labor shortage and milling capacity, for instance, a total of 172,100 ha of sugarcane in the 2012-2013 harvest season in Florida with 12 major cultivars [12]. The fractions of these cultivars in Florida are listed in Figure 4. It is suggested that each of the leading

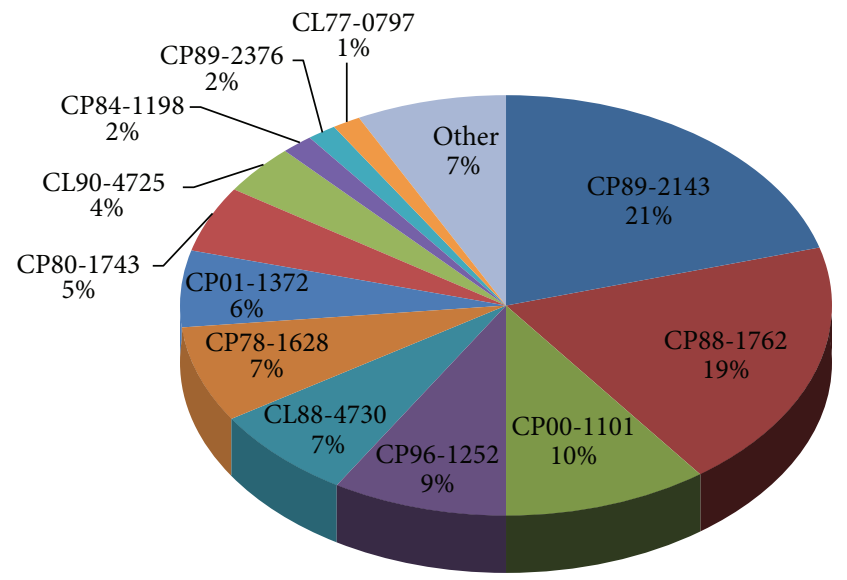

FIgURE 4: Commercial sugarcane cultivars and their \% of total hectarage in the 2012-2013 harvest season in Florida. Total area $=$ 172,118 ha. Data are adopted from Rice et al. [12].

sugarcane cultivars in a region may not be over $25 \%$ of total hectarage in order to mitigate negative effects of the extreme climate events on sugarcane production and to reduce risk of yield losses by some unexpected insects and diseases.

Severity of most sugarcane diseases is associated with the climate related factors. Sugarcane orange rust disease in Florida was much severer in the 2012 and 2013 growing seasons than other years due to warmer winter and higher humidity [37]. Sugarcane smut disease was severer on sandy soils than on organic soils because of high temperature and relative dry conditions. In addition to development of disease resistant cultivars by breeding and variety development programs, integration of the best management practices (BMPs) for pest control and for increases in water and nutrient use efficiencies is also crucial for the climate change adaptation and sugarcane yield improvement. 
These BMPs include carbon sequestration, soil tillage, irrigation methods and scheduling, drainage, nutrient monitoring, and fertilizer applications. All of these are associated with geographic locations and long-term climate change and have been reviewed in detail recently $[15,57]$. Biggs et al. [58] found that the frequency of years with very high $N$ losses is predicted to increase under projected climate change and improved farming practices can more effectively limit $N$ losses than traditional practices. The use of ripeners and withholding irrigation prior to harvest can improve sucrose content of stalks. Additionally, integration of seasonal climate forecasting with proper management strategies has potential to benefit sugarcane production in many areas [59]. The details of cultivar development and management strategies for sugarcane production in China have been proposed [27, $30,60]$. Applications of plant growth regulators can be useful for improving plant tolerance to some specific stresses and for sugar yield enhancement. Studies have indicated that using low concentration of ethylene-producing substances such as ethephon to treat seed canes or yang plants at early growth stage can improve the drought tolerance and mitigate other abiotic stresses of sugarcane plants $[61,62]$. Foliar application of low concentration of ethephon alleviated the injury of cell membrane caused by water deficit stress, maintained relatively lower osmotic rates of electrolytes and soluble sugar, increased the proline content and water potential in the leaf tissues, promoted the activities of cell protective enzymes (such as peroxidase, catalase, and polyphenol oxidase), and improved the gas exchange characteristics. The physiological and biochemical base of plant growth regulator applications and their beneficial effects on sugarcane growth under drought conditions have been reported in detail by Botha et al. [61] and Li [62]. The foliar application of ethephon in a low concentration may be used as a management practice to partly mitigate drought effect on sugarcane growth and yields.

\section{Sugarcane Impact on Local Climate}

In a region, changes in farming systems and crop combinations may directly or indirectly affect local climate factors. Residue burning before or after sugarcane harvest is a common management practice of sugarcane production in many countries. Greenhouse gas emission in sugarcane production is the major concern. A recent research [63] indicated that approximate 2.4 tonnes of $\mathrm{CO}_{2}$ equivalent ha ${ }^{-1}$ was released to the atmosphere by sugarcane crop. The major contributors of the released $\mathrm{CO}_{2}$ from sugarcane were residue burning (44\%), the utilization of synthetic fertilizers $(20 \%)$, and fossil fuel combustion (18\%) [63]. Therefore, improving green harvest can increase soil organic carbon and reduce $\mathrm{CO}_{2}$ emission from sugarcane production.

Georgescu et al. [64] investigated the direct climate effect of perennial bioenergy crops in the United States. Their results demonstrated that a thorough evaluation of costs and benefits of bioenergy-related land-use change must include potential impacts on the surface energy and water balance to comprehensively address important concerns for local, regional, and global climate change. Expansion of sugarcane can relatively increase carbon fixation and carbon sequestration because of its $\mathrm{C}_{4}$ carbon fixation characteristics. A recent study [65] in Brazil, using maps and data from hundreds of satellite images, has revealed that, on a regional basis for clearsky daytime conditions, conversion of natural vegetation to a crop/pasture warms the region by an average of 1.55 (1.45$1.65)^{\circ} \mathrm{C}$, but subsequent conversion of the crop/pasture to sugarcane cools the region by an average of $0.93(0.78-$ $1.07)^{\circ} \mathrm{C}$, resulting in a mean net increase of $0.6^{\circ} \mathrm{C}$. They concluded that expanding sugarcane into existing crop and pasture land has a direct local cooling effect that reinforces the indirect climate benefits of this land-use option. Therefore, sugarcane may be better than other field crops for environmental protection in increasing atmospheric $\left[\mathrm{CO}_{2}\right]$ and surface temperature. Further research is required to reveal the mechanisms of the direct local cooling effect of sugarcane.

\section{Summary and Future Perspectives}

Clearly, sugarcane production has been and will continue to be directly or indirectly affected by changes in climate conditions. The most significant challenges for sugarcane production are increases in frequency and intensity of extreme weather events, especially drought during climate change. Existing adaptation strategies can help offset many but not all effects in the future. The negative effects of climate change on sugarcane production are very likely to worsen after 2050, especially if greenhouse gas emissions still remain high. Therefore, agricultural scientists and decision makers need to work closely to mitigate the potential negative effects of climate change on agriculture and to improve sugarcane yields by multidisciplinary approaches, such as consistently developing new sugarcane cultivars using breeding and molecular biology, refining best management practices, improving new technology transfer, and increasing productivity and profitability. Improving the resilience of sugarcane production systems to climate change requires protection of the natural resource (especially water and soil) for sustainability. Expanding use of sugarcane products for sugar, ethanol, cellulosic biofuel, and other coproducts can further improve profits.

\section{Conflict of Interests}

The authors declare that there is no conflict of interests regarding the publication of this paper.

\section{References}

[1] R. A. Houghton, K. T. Lawrence, J. L. Hackler, and S. Brown, "The spatial distribution of forest biomass in the Brazilian Amazon: a comparison of estimates," Global Change Biology, vol. 7, no. 7, pp. 731-746, 2001.

[2] IPCC, "Summary for policymakers," in Climate Change 2014: Impacts, Adaptation, and Vulnerability. Part A: Global and Sectoral Aspects. Contribution of Working Group II to the Fifth Assessment Report of the Intergovernmental Panel on Climate Change, C. B. Field, V. R. Barros, D. J. Dokken et al., Eds., 
pp. 1-32, Cambridge University Press, Cambridge, UK, 2014, http://www.ipcc.ch/pdf/assessment-report/ar5/wg2/ar5_wgII_ spm_en.pdf.

[3] B. A. Kimball, "Carbon dioxide and agricultural yield: an assemblage and analysis of 430 prior observations," Agronomy Journal, vol. 75, no. 5, pp. 779-788, 1983.

[4] F. Tao, M. Yokozawa, Y. Xu, Y. Hayashi, and Z. Zhang, "Climate changes and trends in phenology and yields of field crops in China, 1981-2000," Agricultural and Forest Meteorology, vol. 138, no. 1-4, pp. 82-92, 2006.

[5] K. E. Trenberth, P. D. Jones, P. Ambenje et al., "Observations: surface and atmospheric climate change: the physical science basis," in Contribution of WG 1 to the Fourth Assessment Report of the Intergovernmental Panel on Climate Change, S. Solomon, D. Qin, M. Manning et al., Eds., pp. 235-336, Cambridge University Press, Cambridge, UK, 2007.

[6] R. S. Dhillon and G. von Wuehlisch, "Mitigation of global warming through renewable biomass," Biomass and Bioenergy, vol. 48, pp. 75-89, 2013.

[7] J. Gawander, "Impact of climate change on sugar-cane production in Fiji," WMO Bulletin, vol. 56, pp. 34-39, 2007.

[8] C. Rosenzweig, G. Casassa, D. J. Karoly et al., "Assessment of observed changes and responses in natural and managed systems," in Climate Change 2007: Impacts, Adaptation and Vulnerability. Contribution of Working Group II to the Fourth Assessment Report of the Intergovernmental Panel on Climate Change, M. L. Parry, O. F. Canziani, J. P. Palutikof, P. J. van der Linden, and C. E. Hanson, Eds., pp. 79-131, Cambridge University Press, Cambridge, UK, 2007.

[9] P. K. Thornton, P. G. Jones, G. Alagarswamy, and J. Andresen, "Spatial variation of crop yield response to climate change in East Africa," Global Environmental Change, vol. 19, no. 1, pp. 5465, 2009.

[10] D. B. Lobell, M. B. Burke, C. Tebaldi, M. D. Mastrandrea, W. P. Falcon, and R. L. Naylor, "Prioritizing climate change adaptation needs for food security in 2030," Science, vol. 319, no. 5863, pp. 607-610, 2008.

[11] A. Anderson-Sprecher and J. Jiang, "China: sugar annual," Report 14020, USDA Foreign Agricultural Service, Global Agricultural Information Network (GAIN), 2014, http://gain .fas.usda.gov/Recent\%20GAIN\%20Publications/Sugar\%20Annual_Beijing_China\%20-\%20Peoples\%20Republic\%20of_4-302014.pdf.

[12] R. Rice, L. Baucum, and B. Glaz, "Sugarcane variety census: Florida 2012," Sugar Journal, vol. 76, no. 2, pp. 11-19, 2013.

[13] FAO, "Report, Food and Agricultural Organization, United Nations: Economic and Social Department," The Statistical Division, FAO 2013 FAOSTAT, 2014, http://faostat3.fao.org/ home/index.html\#DOWNLOAD.

[14] Factfish, "Sugar cane, production quantity (tons) - for all countries," 2015, http://www.factfish.com/statistic/sugar+cane,+production+quantity.

[15] M. Chandiposha, "Potential impact of climate change in sugarcane and mitigation strategies in Zimbabwe," African Journal of Agricultural Research, vol. 8, pp. 2814-2818, 2013.

[16] F. R. Marin, J. W. Jones, A. Singels et al., "Climate change impacts on sugarcane attainable yield in southern Brazil," Climatic Change, vol. 117, no. 1-2, pp. 227-239, 2013.

[17] J. C. V. Vu and L. H. Allen Jr., "Growth at elevated $\mathrm{CO}_{2}$ delays the adverse effects of drought stress on leaf photosynthesis of the C4 sugarcane," Journal of Plant Physiology, vol. 166, no. 2, pp. 107-116, 2009.

[18] J. C. V. Vu and L. H. Allen Jr., "Stem juice production of the $\mathrm{C}_{4}$ sugarcane (Saccharum officinarum) is enhanced by growth at double-ambient $\mathrm{CO}_{2}$ and high temperature," Journal of Plant Physiology, vol. 166, no. 11, pp. 1141-1151, 2009.

[19] A. P. de Souza, M. Gaspar, E. A. da Silva et al., "Elevated $\mathrm{CO}_{2}$ increases photosynthesis, biomass and productivity, and modifies gene expression in sugarcane," Plant, Cell and Environment, vol. 31, no. 8, pp. 1116-1127, 2008.

[20] S. Chakraborty, G. M. Murray, P. A. Magarey et al., "Potential impact of climate change on plant diseases of economic significance to Australia," Australasian Plant Pathology, vol. 27, no. 1, pp. 15-35, 1998.

[21] A. G. Hayes, "Weather trends at Condong, NSW," Proceedings of the Australian Society of Sugar Cane Technologists, vol. 12, pp. 39-44, 1990.

[22] A. L. de Carvalho, R. S. C. Menezes, R. S. Nóbrega et al., "Impact of climate changes on potential sugarcane yield in Pernambuco, northeastern region of Brazil," Renewable Energy, vol. 78, pp. 26-34, 2015.

[23] D. L. Santos and P. C. Sentelhas, "Climate change scenarios and their impact on the water balance of sugarcane production areas in the State of São Paulo, Brazil," Ambiente e Agua, vol. 7, no. 2, pp. 7-17, 2012.

[24] J. W. Knox, J. A. Rodríguez Díaz, D. J. Nixon, and M. Mkhwanazi, "A preliminary assessment of climate change impacts on sugarcane in Swaziland," Agricultural Systems, vol. 103, no. 2, pp. 63-72, 2010.

[25] B. Singh and M. El Maayar, "Potential impacts of a greenhouse gas climate change scenarios on sugar cane yields in Trinidad, southern Caribbean," Tropical Agriculture, vol. 75, no. 3, pp. 348-355, 1998.

[26] A. F. P. de Lucena, A. S. Szklo, R. Schaeffer et al., "The vulnerability of renewable energy to climate change in Brazil," Energy Policy, vol. 37, no. 3, pp. 879-889, 2009.

[27] Y.-R. Li and Y.-A. Wei, "Sugar industry in China: R \& D and policy initiatives to meet sugar and biofuel demand of future," Sugar Tech, vol. 8, no. 4, pp. 203-216, 2006.

[28] R. A. Gilbert, C. R. Rainbolt, D. R. Morris, and A. C. Bennett, "Morphological responses of sugarcane to long-term flooding," Agronomy Journal, vol. 99, no. 6, pp. 1622-1628, 2007.

[29] A. Challinor, T. Wheeler, C. Garforth, P. Craufurd, and A. Kassam, "Assessing the vulnerability of food crop systems in Africa to climate change," Climatic Change, vol. 83, no. 3, pp. 381-399, 2007.

[30] Y. R. Li and L. T. Yang, "Chinese sugarcane and sugar industry in recent 10 years," in Proceedings of the 5th International Association of Professionals in Sugar and Integrated Technologies: Green Technologies for Sustanable Growth of Sugar \& Integrated Industries in Developing Countries, Y.-R. Li, G. P. Rao, S. Solomon et al., Eds., pp. 1-10, 2014.

[31] Y. R. Li, F. X. Fang, L. T. Yang et al., "Long duration cold stress and frost induced losses to sugarcane production in Guangxi (China) during 2010-11 and its control measures," in Proceedings of the 4th IAPSIT International Sugar Conference (IS '11) \& Expo (Balancing Sugar and Energy Production in Developing Countries: Sustainable Technologies and Marketing Strategies), pp. 353-358, Army Printing Press, IBDC Publishers, Lucknow, India, 2011. 
[32] R. A. Gilbert, C. R. Rainbolt, D. R. Morris, and J. M. McCray, "Sugarcane growth and yield responses to a 3-month summer flood," Agricultural Water Management, vol. 95, no. 3, pp. 283291, 2008

[33] B. Glaz and S. E. Lingle, "Flood duration and time of flood onset effects on recently planted sugarcane," Agronomy Journal, vol. 104, no. 3, pp. 575-583, 2012.

[34] L. Matthieson, "Climate change and the Australian Sugarcane Industry: impacts, adaptation and R\&D opportunities," SRDC Technical Report, Sugar Research and Development, Brisbane, Australia, 2007.

[35] Y. L. Everingham, R. C. Muchow, R. C. Stone, N. G. InmanBamber, A. Singels, and C. N. Bezuidenhout, "Enhanced risk management and decision-making capability across the sugarcane industry value chain based on seasonal climate forecasts," Agricultural Systems, vol. 74, no. 3, pp. 459-477, 2002.

[36] D. Zhao, N. C. Glynn, B. Glaz, J. C. Comstock, and S. Sood, "Orange rust effects on leaf photosynthesis and related characters of sugarcane," Plant Disease, vol. 95, no. 6, pp. 640-647, 2011.

[37] D. Zhao, R. W. Davidson, M. Baltazar, and J. C. Comstock, "Field evaluation of sugarcane orange rust for first clonal stage of the CP cultivar development program," American Journal of Agricultural and Biological Sciences, vol. 10, no. 1, pp. 1-11, 2015.

[38] R. N. Raid, J. C. Comstock, and S. Sood, "Sugarcane orange rust in Florida: its history, current status, and management," Journal of the American Society of Sugar Cane Technologists, vol. 33, p. $57,2013$.

[39] J. C. Comstock, S. G. Sood, N. C. Glynn, J. M. Shine Jr., J. M. McKemy, and L. A. Castlebury, "First report of Puccinia kuehnii, causal agent of orange rust of sugarcane, in the United States and in the Western Hemisphere," Plant Disease, vol. 92, p. 175, 2008.

[40] T. Deressa, R. Hassan, and D. Poonyth, "Measuring the impact of climate change on south african agriculture: the case of sugarcane growing regions," Agrekon, vol. 44, no. 4, pp. 524-542, 2005.

[41] N. G. Inman-Bamber, P. Lakshmanan, and S. Park, "Sugarcane for water-limited environments: theoretical assessment of suitable traits," Field Crops Research, vol. 134, pp. 95-104, 2012.

[42] P. P. da Silva, L. Soares, J. G. da Costa et al., "Path analysis for selection of drought tolerant sugarcane genotypes through physiological components," Industrial Crops and Products, vol. 37, no. 1, pp. 11-19, 2012.

[43] D. Zhao, B. Glaz, and J. C. Comstock, "Sugarcane leaf photosynthesis and growth characters during development of waterdeficit stress," Crop Science, vol. 53, no. 3, pp. 1066-1075, 2013.

[44] A. L. C. De Silva and W. A. J. M. De Costa, "Growth and radiation use efficiency of sugarcane under irrigated and rainfed conditions in Sri Lanka," Sugar Tech, vol. 14, no. 3, pp. 247254, 2012.

[45] N. Robinson, A. Fletcher, A. Whan et al., "Sugarcane genotypes differ in internal nitrogen use efficiency," Functional Plant Biology, vol. 34, no. 12, pp. 1122-1129, 2007.

[46] D. Zhao, B. Glaz, and J. C. Comstock, "Physiological and growth responses of sugarcane genotypes to nitrogen rate on a sand soil," Journal of Agronomy and Crop Science, vol. 200, no. 4, pp. 290-301, 2014.

[47] S. J. Edmé, J. D. Miller, B. Glaz, P. Y. P. Tai, and J. C. Comstock, "Genetic contribution to yield gains in the Florida sugarcane industry across 33 years," Crop Science, vol. 45, no. 1, pp. 92-97, 2005.
[48] D. Zhao, B. Glaz, M. S. Irey, and C.-J. Hu, "Sugarcane genotype variation in leaf photosynthesis properties and yield as affected by mill mud application," Agronomy Journal, vol. 107, no. 2, pp. 506-514, 2015.

[49] M. Menossi, M. C. Silva-Filho, M. Vincentz, M.-A. Van-Sluys, and G. M. Souza, "Sugarcane functional genomics: gene discovery for agronomic trait development," International Journal of Plant Genomics, vol. 2008, Article ID 458732, 11 pages, 2008.

[50] J. Todd, B. Glaz, D. Burner, and C. Kimbeng, "Historical use of cultivars as parents in Florida and Louisiana sugarcane breeding programs," International Scholarly Research Notices, vol. 2015, Article ID 257417, 9 pages, 2015.

[51] M. D. da Silva, R. L. D. O. Silva, J. R. Costa Ferreira Neto et al., "analysis of sugarcane aquaporin genes under water deficit," Journal of Nucleic Acids, vol. 2013, Article ID 763945, 14 pages, 2013.

[52] J. Grice, M. K. Wegener, L. M. Romanach, S. Paton, P. Bonaventura, and S. Garrad, "Genetically modified sugarcane: a case for alternate products," AgBioForum, vol. 6, no. 4, pp. 162-168, 2003.

[53] GRAIN, "Corporate candyland: the looming GM sugar cane invasion," Seedling, vol. 4, no. 1, pp. 2-12, 2009.

[54] P. A. Joyce, S.-Q. Dinh, E. M. Burns, and M. G. O’shea, "Sugar from genetically modified sugarcane: tracking transgenes, transgene products and compositional analysis," International Sugar Journal, vol. 12, pp. 860-863, 2013.

[55] R. C. Magarey, B. J. Croft, and T. G. Willcox, "An epidemic of orange rust on sugarcane in Australia," in Proceedings of the 24th Congress of the International Society of Sugar Cane Technologists, pp. 410-416, Brisbane, Australia, September 2001.

[56] K. S. Braithwaite, B. J. Croft, R. C. Magarey, and T. Scharaschkin, "Phylogenetic placement of the sugarcane orange rust pathogen Puccinia kuehnii in a historical and regional context," Australasian Plant Pathology, vol. 38, no. 4, pp. 380-388, 2009.

[57] A. Bhaskaran and N. V. Nair, "Challenges and opportunities in sugarcane cultivation under climate change scenario," Journal of Sugarcane Research, vol. 4, pp. 1-18, 2014.

[58] J. S. Biggs, P. J. Thorburn, S. Crimp, B. Masters, and S. J. Attard, "Interactions between climate change and sugarcane management systems for improving water quality leaving farms in the Mackay Whitsunday region, Australia," Agriculture, Ecosystems and Environment, vol. 180, pp. 79-89, 2013.

[59] R. C. Muchow, A. J. Higgins, N. G. Inman-Bamber, and P. J. Thorburn, "Towards sustainable sugarcane production using a whole systems analysis approach," in Proceedings of the 24th Congress of the International Society of Sugar Cane Technologists, pp. 91-94, Brisbane, Australia, September 2001.

[60] Y.-R. Li and L.-T. Yang, "Research and development priorities for sugar industry of China: recent research highlights," Sugar Tech, vol. 17, no. 1, pp. 9-12, 2014.

[61] F. C. Botha, P. Lakshmanan, A. O'Connell, and P. H. Moore, "Hormones and growth regulators," in Sugarcane: Physiology, Biochemistry, and Functional Biology, P. H. Moore and F. C. Botha, Eds., pp. 331-378, John Wiley \& Sons, 2014.

[62] Y.-R. Li, "Beneficial effects of ethephon application on sugarcane under sub-tropical climate of China," Sugar Tech, vol. 6, no. 4, pp. 235-240, 2004.

[63] E. B. de Figueiredo, A. R. Panosso, R. Romão, and N. La Scala Jr., "Greenhouse gas emission associated with sugar production in southern Brazil," Carbon Balance and Management, vol. 5, article 3, 2010. 
[64] M. Georgescu, D. B. Lobell, and C. B. Field, "Direct climate effects of perennial bioenergy crops in the United States," Proceedings of the National Academy of Sciences of the United States of America, vol. 108, no. 11, pp. 4307-4312, 2011.

[65] S. R. Loarie, D. B. Lobell, G. P. Asner, Q. Mu, and C. B. Field, "Direct impacts on local climate of sugar-cane expansion in Brazil," Nature Climate Change, vol. 1, no. 2, pp. 105-109, 2011. 


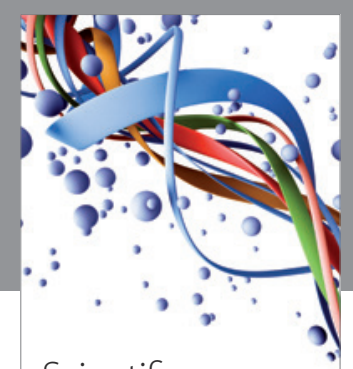

Scientifica
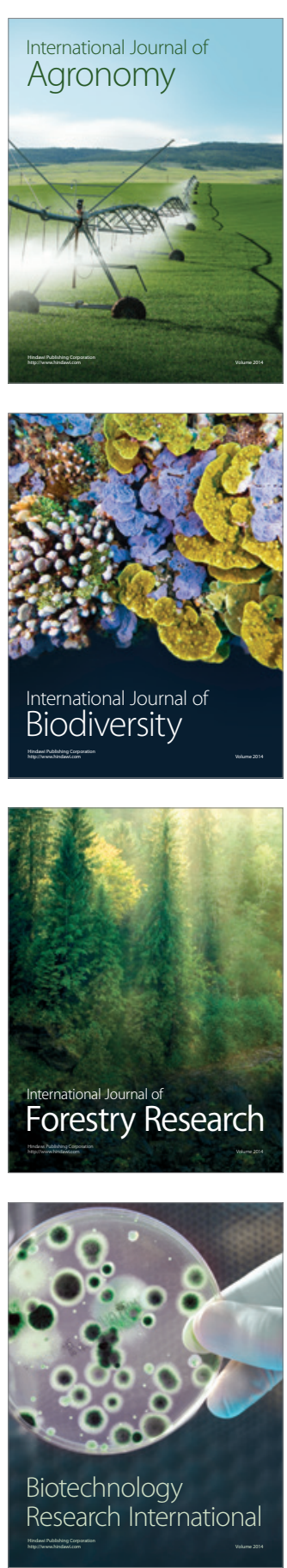
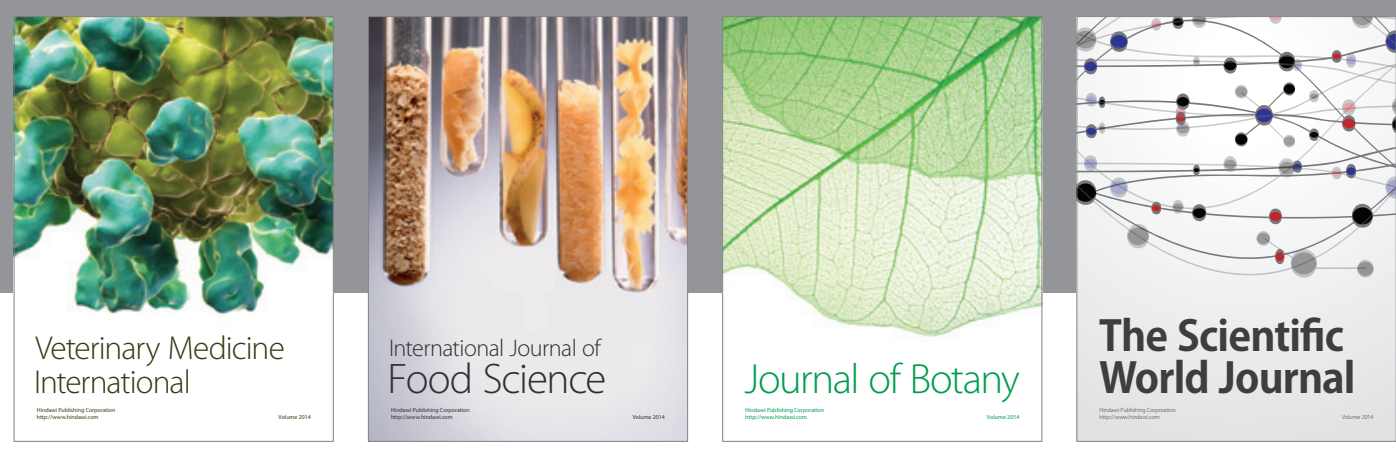

The Scientific World Journal
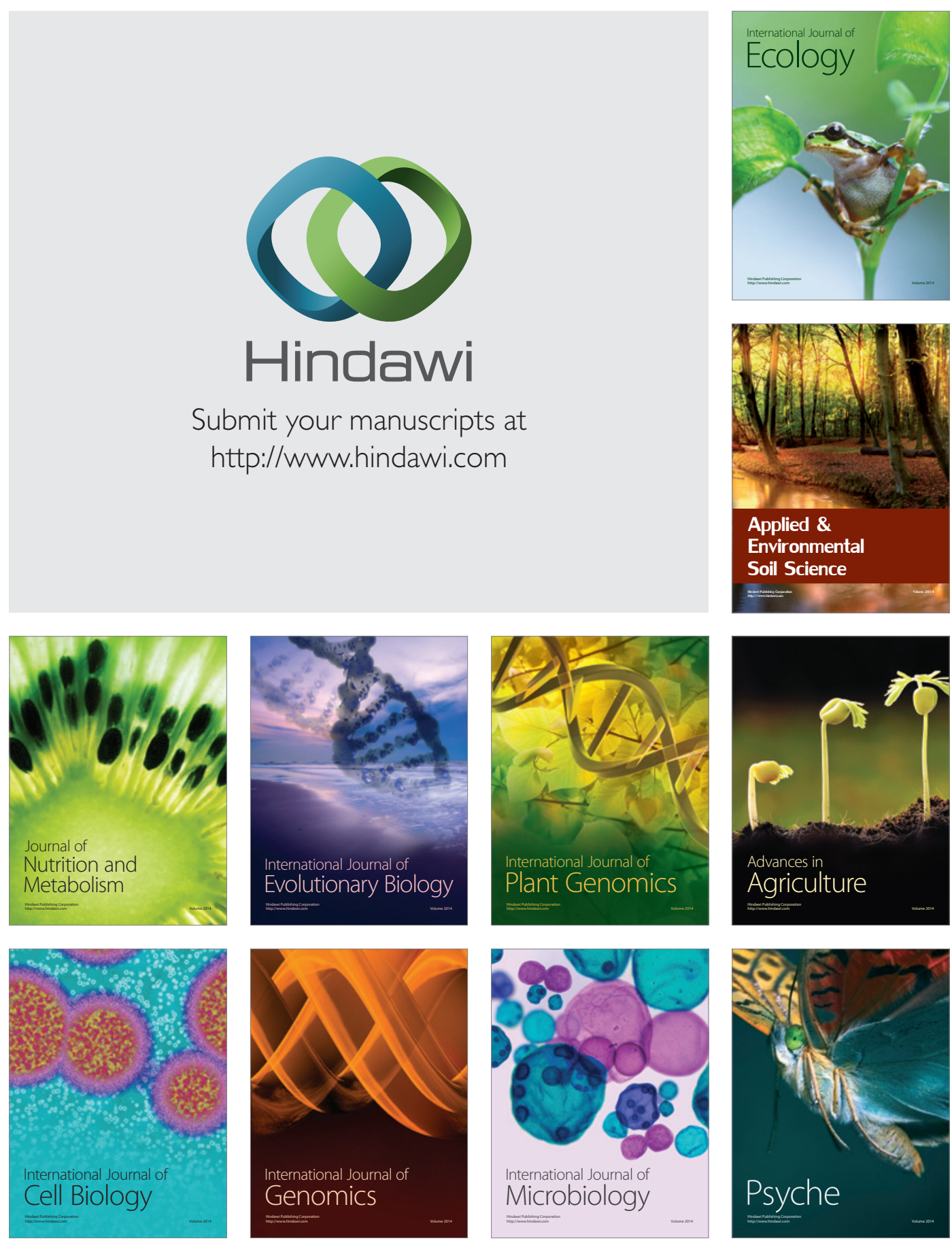